Faraday Rediscovered 


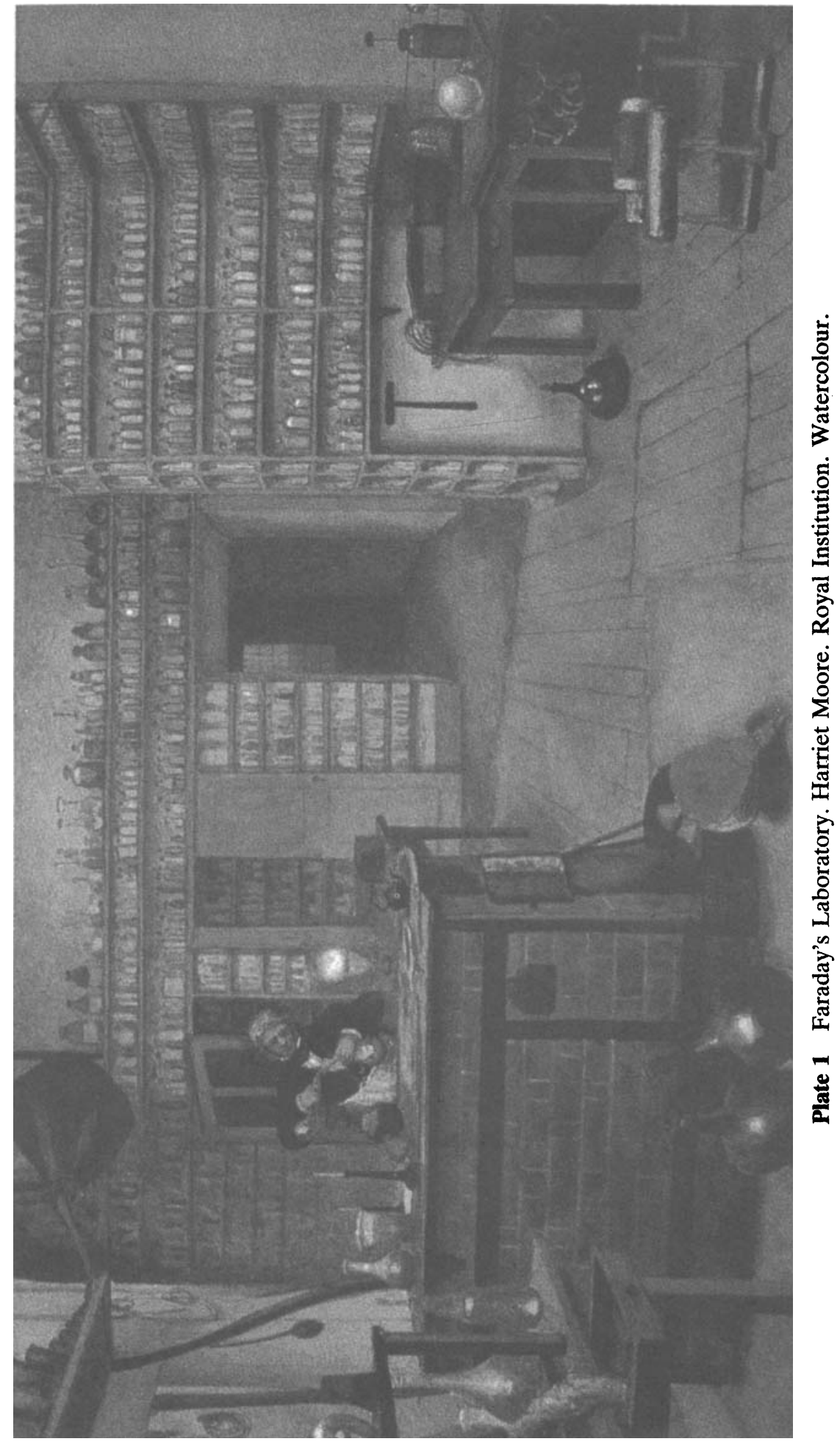




\title{
FARADAY REDISCOVERED
}

Essays on the Life and Work of Michael Faraday, 1791-1867

Edited and Introduced by

\author{
David Gooding \\ Frank A. J. L. James
}

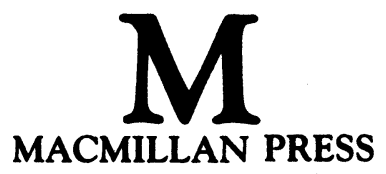


(C) The contributors 1985

All rights reserved. No reproduction, copy or transmission of this publication may be made without written permission.

No paragraph of this publication may be reproduced, copied or transmitted save with written permission or in accordance with the provisions of the Copyright Act 1956 (as amended).

Any person who does any unauthorised act in relation to this publication may be liable to criminal prosecution and civil claims for damages.

First edition 1985

Reprinted (with corrections) 1989

Published by

THE MACMILLAN PRESS LTD

Brunel Road, Houndmills, Basingstoke, Hants RG21 2XS, England

British Library Cataloguing in Publication Data

Faraday rediscovered: essays on the life and

work of Michael Faraday, 1791-1867.

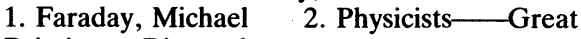

Britain-Biography

I. Gooding, David II. James, Frank A. J. L.

530'.092' QC16.F2

ISBN 978-0-333-51122-0 ISBN 978-1-349-11139-8 (eBook)

DOI 10.1007/978-1-349-11139-8 


\section{Contents}

List of Plates vii

Notes on Contributors viii

Foreword Professor Sir George Porter xi

Preface xiii

Introduction: Faraday Rediscovered David Gooding and Frank A.J.L. James 1

1 Faraday: Image of the Man and the Collector Gertrude M. Prescott $\quad 15$

2 Davy and Faraday: Fathers and Sons David M. Knight 33

3 Faraday - From Servant to Savant: The Institutional Context Sophie Forgan 51

4 Reading the Book of Nature: The Relation between Faraday's Religion and his Science Geoffrey N. Cantor 69

5 Faraday and Ampère: A Critical Dialogue L. Pearce Williams 83

6 'In Nature's School': Faraday as an Experimentalist David Gooding $\quad 105$

7 'The Optical Mode of Investigation': Light and Matter in Faraday's Natural Philosophy Frank A.J.L. James 137

8 Faraday, Wheatstone and Electrical Engineering Brian Bowers 163

9 Faraday's Field Concept Nancy J. Nersessian 175

10 Faraday's Discovery of Induction: A Cognitive Approach Ryan D. Tweney 
11 Learning from Experience Elspeth Crawford

Bibliographical Notes

229

Collected Bibliography

233

Index 


\section{List of Plates}

$1 \quad$ Faraday's Laboratory

Page

2 Michael Faraday reading a newspaper

3 Mary Somerville

4 'A Collector'

5 Justus Liebig

6 Humphry Davy

7 Humphry Davy

8 William Hyde Wollaston

$9 \quad$ Faraday lecturing

10 Bust of Michael Faraday

11 André-Marie Ampère

12 Faraday's manuscript Diary

13 Michael Faraday with apparatus

14 John Barlow

15 Charles Wheatstone

16 Michael Faraday holding a bar magnet 


\section{Notes on Contributors}

Brian Bowers is Curator of Lighting and Electric Power in the Science Museum, London. He was educated at King's College, London where he became interested in Charles Wheatstone, the subject of his doctoral thesis. His publications include $A$ History of Electric Light and Power and $A$ Children's Biography of Faraday.

Address: Department of Electrical Engineering, Science Museum, Exhibition Road, London, SW7 2DD, England.

Geoffrey N. Cantor lectures in the history and philosophy of science at the University of Leeds. He is the author of Optics after Newton and co-editor of Conceptions of Ether. Following on from the paper published in this volume he intends to make a more extensive study of Faraday and the London Sandemanians.

Address: Department of Philosophy, University of Leeds, Leeds, LS2 9JT, England.

Elspeth Crawford graduated in mathematics from Queen's University, Belfast, taught young children for some years, then returned to academic work studying history and philosophy of science at Chelsea College, University of London. She completed her doctoral thesis in 1985 on 'The ideas of particle and field in Michael Faraday's work 1831-1845'. She has also been a tutor in scientific education at the University of London Institute of Education and currently teaches physics at North London Collegiate School.

Address: 105 Broadhurst Gardens, London, NW6 3BJ, England.

Sophie Forgan was educated at London University where she completed her doctoral thesis on the Royal Institution in 1977. She lectures in history of design at Teesside Polytechnic. Her research interests include the history of 
learned societies, and the relations between architecture, science and society. Address: Department of Design, Teesside Polytechnic, Middlesbrough, Cleveland, TS1 3BA, England.

David Gooding is Senior Lecturer in History and Philosophy of Science at the University of Bath and is a Visiting Research Fellow of the Royal Institution Centre for the History of Science and Technology. He has published several articles on Faraday, is writing a biography of Faraday and is studying the influence of the practical experimental contexts of nineteenth-century science on the ways that scientists describe nature.

Address: School of Humanities and Social Science, University of Bath, Claverton Down, Bath, Avon, BA2 7AY, England.

Frank A. J. L. James is Secretary of the Royal Institution Centre for the History of Science and Technology, London, he is also Lecturer in History of Science. His main research interest is in nineteenth-century physical science and its cultural context. He has recently completed an edition of the diary of Herbert McLeod from 1860 to 1870.

Address: Royal Institution Centre for the History of Science and Technology, The Royal Institution, 21 Albemarle Street, London, W1X 4BS, England.

David M. Knight teaches history and philosophy of science in the Philosophy Department of the University of Durham. He is the editor of the British Journal for the History of Science. He has written and edited several books including The Nature of Science, Natural Science Books in English and The Transcendental Part of Chemistry.

Address: Department of Philosophy, University of Durham, 50 Old Elvet, Durham, DH1 3HN, England.

Nancy J. Nersessian was formerly Associate Professor of the History and Philosophy of Science at the Technical University of Twente, and a Research Fellow at the Centre for Philosophy of Science at the University of Pittsburgh. She has been a Fulbright Research Scholar at the University of Leiden, a Fellow of the Netherlands Institute for Advanced Study, and is editor of the Science and Philosophy series published by Martinus Nijhoff.

Address: Program in History of Science, Princeton University, 220 Palmer Hall, Princeton, NJ 08544, USA.

Gertrude M. Prescott is Assistant Curator, Iconography Collections, Wellcome Institute for the History of Medicine. She was educated at Princeton 
University and the University of Texas at Austin where she is currently completing her doctoral thesis on portrait publications in nineteenth-century Britain. She was a Fulbright Scholar and is a Visiting Research Scholar at the Royal Institution Centre for the History of Science and Technology.

Address: Wellcome Institute for the History of Medicine, 183 Euston Road, London, NW1 2BP, England.

Ryan D. Tweney is Professor of Psychology at Bowling Green State University. He co-edited (with M.E. Doherty and C.R. Mynatt) On Scientific Thinking and (with W. Bringmann) Wundt Studies. He is currently conducting research on the cognitive psychology of science with a special focus on the inferential heuristics of Michael Faraday.

Address: Department of Psychology, Bowling Green State University, Bowling Green, Ohio 43403, USA.

L. Pearce Williams is the John Stambaugh Professor of the History of Science at Cornell University and the author of Michael Faraday, A Biography, Album of Science: The Nineteenth Century and The Origins of Field Theory. He is working on a biography of André-Marie Ampère.

Address: Department of History, McGraw Hall, Cornell University, Ithaca, New York 14853, USA. 


\section{Foreword}

Those of us who are fortunate enough to work here in Faraday's laboratory and even, in my case, to live in his home, feel his influence all around us. Never have a great scientist and a building been so closely linked. This happy association, coupled with the meticulous way in which he recorded all his work and the fact that his successors were wise enough to keep carefully the great quantity of experimental apparatus he left behind, has resulted in the happy circumstance that we have, for our greatest experimentalist, the most complete historical record of the artefacts of a single scientist to be found anywhere.

Much has been written about Faraday and much more will be written and read - not only because of the enormous significance of his discoveries and the profusion of historical material, but also because his life has a romantic 'rags to riches' quality and a nearness to perfection which will forever be an inspiration to those whose love for science may seem to be unmatched by opportunity or formal education.

I hope that these studies will encourage scholars to 'rediscover' Faraday and to understand better the ways of working of his great mind. The new aspects of his life and achievements revealed here will also be of interest to the many people by whom he is revered throughout the world.

The Royal Institution, July 1985

GEORGE PORTER, FRS

Director and

Fullerian Professor of Chemistry 
For our families 


\section{Preface}

There are many studies of the life and work of Michael Faraday (1791-1867). None of these are definitive and this book does not aim to be so. Our title, Faraday Rediscovered, recalls John Tyndall's Faraday as a Discoverer, the first account of Faraday's considerable experimental achievements. It conveys our intention to promote a fresh approach to Faraday, whose work has been obscured by preconceptions about science and by heroic myths about its practitioners. We have brought together recent essays on Faraday which point the way for future studies of Faraday and of nineteenth century science generally.

Earlier versions of these essays were presented at the conference 'Faraday Rediscovered' held from 19 to 21 September 1984 at the Royal Institution, with one morning session at the Institution of Electrical Engineers. The conference was a forum in which new work was discussed and criticised. A strength of the meeting was its emphasis on the performance of experimental demonstrations. However, since not all demonstrations and lectures lent themselves to a literary rendering, some have, we regret, been omitted. The central place of experiment in Faraday's work is none the less a dommant theme in several that we have included.

The demonstrations were a striking feature of the conference. They also showed the unique contribution that the Royal Institution continues to make to British intellectual life. No other institution in the country combines a major scientific collection, demonstration skills, conference and library facilities and the personnel that allowed the conference to develop in the way it did.

Not all the demonstrations were successful, as the case of one of us (DG) illustrates. His experiments had been set up before we went to the Institution of Electrical Engineers for the morning session. We returned to the Royal Institution through a heavy rainstorm. Fifty wet historians increased the humidity in the lecture theatre so much that none of the electroscopes functioned. This illustrates Coates's law of electrostatics: 'keep your audience 
dry'. One of the themes of this book is that failed experiments often provide as much information as successful experiments do.

All the other demonstrations worked. We are particularly grateful to Professor Sir George Porter and Professor Ronald King for their demonstration lectures respectively on Faraday's chemical experiments and his electromagnetic induction experiments. We thank Bill Coates, Senior Experimental Officer, and his staff for the immense effort they put into providing these demonstrations.

Contributors make their acknowledgements at the end of each essay, but we would like to make our joint acknowledgements here. We thank the Director of the Royal Institution, the Council of the Royal Institution and the Steering Committee of the Royal Institution Centre for the History of Science and Technology for supporting the conference and this book. DG wishes to thank them particularly for appointing him a Visiting Research Fellow of the Centre. He also thanks the School of Humanities and Social Science of the University of Bath for a study leave during the spring term of 1984, and the Royal Society for financial support during that period. We acknowledge the award of a travel grant by the British Academy for Dr Nancy Nersessian that allowed her to attend the conference. We thank Lenore Symons, Archivist of the Institution of Electrical Engineers and Irena McCabe, Librarian and Information Officer of the Royal Institution for their support during the conference (the latter, especially, for organising a display of Faradaiana in the library) and for their subsequent patience in dealing with our many editorial queries of the Faraday holdings in both archives.

We thank the Royal Institution for permission to reproduce Plates 1, 3-10, 12-14; the Institution of Electrical Engineers, Plates 11 and 15; Glasgow University Library, Plate 2 and the National Portrait Gallery, Plate 16. 